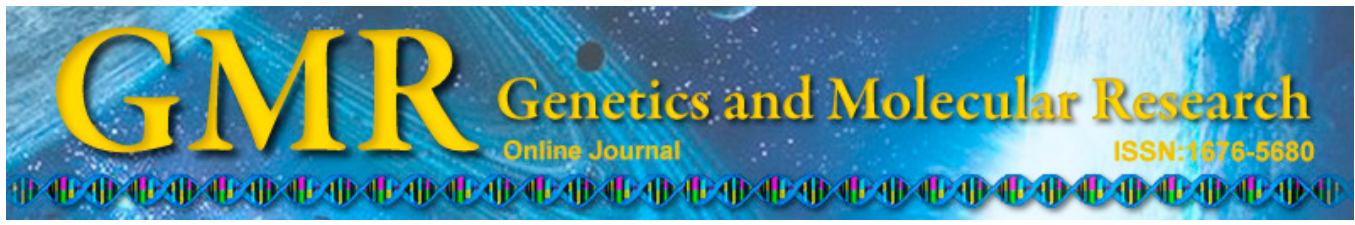

\title{
Cohn process influences the functional anticoagulant activity of human protein $\mathrm{C}$
}

\author{
Z.K. Wang', X. Du ${ }^{1}$, Y.M. Wang ${ }^{2}$, C.Q. Li ${ }^{1}$, F.Z. Lin ${ }^{1}$, H.J. Cao ${ }^{1}$, S.L. Ye ${ }^{1}$, \\ J.J. Hu${ }^{2}$ and J. Yuan ${ }^{2}$ \\ ${ }^{1}$ Institute of Blood Transfusion, \\ Chinese Academy of Medical Sciences \& Peking Union Medical College, \\ Chengdu, China \\ ${ }^{2}$ Guizhou Taibang Biological Products Co., Ltd., Guiyang, China \\ Corresponding author: C.Q. Li \\ E-mail: lichangqing268@163.com
}

Genet. Mol. Res. 14 (1): 860-870 (2015)

Received December 19, 2013

Accepted March 28, 2014

Published February 2, 2015

DOI http://dx.doi.org/10.4238/2015.February.2.10

\begin{abstract}
Cohn fraction IV (CFIV) is a byproduct of a plasma fractionation process known as the Cohn process. It is an inexpensive source of protein $\mathrm{C}$, retaining about $90 \%$ of protein $\mathrm{C}(\mathrm{PC})$ in human plasma. We investigated whether $\mathrm{PC}$ is affected during the Cohn process and evaluated correlations among coagulant activity, amidolytic activity and PC antigen during the Cohn process. CFIV was redissolved with citrate-buffered saline for $5 \mathrm{~h}$ at $4^{\circ} \mathrm{C}$, and then centrifuged at 3500 $g$ for $40 \mathrm{~min}$ at $4^{\circ} \mathrm{C}$. Functional anticoagulant activity was measured with a one-stage coagulation method based on activated partial thromboplastin time. The functional amidolytic activity of PC was determined using chromogenic substrate assay, and measurement of PC antigen was performed by ELISA. In CFIV, anticoagulant activity declined significantly, with a loss of $>80 \%$, while amidolytic activity was not significantly altered, compared to PC antigen. Prior to the Cohn process, high-rank correlations were observed in cryosupernatant, with $r_{s}=0.921$ for anticoagulant and amidolytic activities $(P=0.009)$, 0.896 for anticoagulant activity and antigen $(\mathrm{P}=0.014)$ and 0.832 for
\end{abstract}


amidolytic activity and antigen $(\mathrm{P}=0.031)$. After the Cohn process in CFIV, there was also a high correlation between amidolytic activity and antigen $\left(r_{s}=0.782, P=0.038\right)$. There were no significant correlations between anticoagulant activity and antigen $\left(r_{s}=0.223, P=0.653\right)$, or anticoagulant and amidolytic activity $\left(\mathrm{r}_{\mathrm{s}}=0.236, \mathrm{P}=0.675\right)$. We conclude that the Cohn process significantly influences the anticoagulant activity of PC. Compared to the antigen, PC lost greater than $80 \%$ of its anticoagulant activity, but retained its amidolytic activity, during the Cohn process.

Key words: Protein C; Anticoagulant activity; Amidolytic activity; Cohn process

\section{INTRODUCTION}

Human protein C (PC), a 62-kDa vitamin K-dependent zymogen of serine protease, is a glycoprotein mainly synthesized in the liver (Kisiel, 1979; Athanasiadis et al., 2011). Its structure is similar to other vitamin K-dependent proteins that affect blood clotting, such as factor II, VII, IX, and X. It is the pivotal anticoagulant and antithrombotic protein in the human coagulation cascade and regulates blood coagulation by inactivating activated factors $\mathrm{V}$ and VIII in the presence of calcium ions and phospholipids (Kisiel et al., 1977; Griffin et al., 1982; Esmons, 1989, 2012). In addition, PC has antiapoptic and anti-inflammatory properties, although the molecular mechanism responsible for these properties is not wellunderstood (Dettenmeier et al., 2003; Mosnier et al., 2007; Ní Ainle et al., 2011). Recent studies revealed that PC has neuroprotective effects and mediates new blood vessel formation and neurogenesis after controlled cortical impact (Petraglia et al., 2010). PC is a trace protein that is quite labile at an average concentration of $4 \mathrm{mg} / \mathrm{L}$, with a half-life of $6 \mathrm{~h}$ in human blood (Esmon, 2012).

However, hereditary deficiency of PC can reduce the body's ability to prevent thrombosis as well as increase the risk of sepsis, deep vein thrombosis, and other clotting complications (Miletich et al., 1987; Hasstedt et al., 1998; Hoshi et al., 2007; Toussaint and Gerlach, 2009; Heleen van Ommen and Middeldorp, 2011; Brummel-Ziedins et al., 2012; Tang et al., 2012). Furthermore, acquired PC deficiency is frequently observed in meningococcemia, hepatopathy, and bone marrow transplant recipients. Currently, fresh frozen plasma, heparin, and Coumadin are used to treat PC deficiency and other hypercoagulable conditions (International Warfarin Pharmacogenetics et al., 2009). However, the therapeutics of fresh frozen plasma requires frequent infusions once or twice daily to achieve significant symptom improvement, which can lead to volume overload (Marlar et al., 1992) and increase the risk of blood-borne infections, such as human immunodeficiency virus, hepatitis B virus, and human parvovirus (Wu and Bruley, 2002). Two other methods, heparin and Coumadin, may cause harmful side effects, such as skin necrosis and excessive bleeding, which are life-threatening. Moreover, pregnant women cannot use Coumadin (Schramm, 1993).

Plasma-derived PC concentrates are efficient and display an excellent safety profile. They are generally well-tolerated and have no reported drug interactions, blood-borne infections, bleeding, or prothrombotic complications (Dreyfus et al., 2007; Kroiss and Albisetti, 2010). Until 2002, PC-related diseases have resulted in 300,000 hospitalizations and 50,000 
deaths in the United States (Wu and Bruley, 2002). This places a substantial economic burden on the healthcare system (Wu and Bruley, 2002). The incidence rate of PC deficiency is 1 in 300 people, whereas the incidence of clinically significant PC deficiency is estimated to be 1 in 20,000 worldwide (Dahlbäck and Villoutreix, 2003). Therefore, therapeutic replacement of $\mathrm{PC}$ is a preferable alternative if large quantities of PC can be produced inexpensively.

Cohn fraction IV (CFIV), a byproduct of the Cohn process, often discarded, particularly in developing countries, retains over $90 \%$ of PC in the plasma and contains several homologous vitamin K-dependent proteins, such as factor II, VII, IX, and X, as well as other plasma proteins (Lee et al., 2008). The Cohn process, also known as cold ethanol fractionation, is a series of purification steps developed by Cohn et al. (1946) during World War II to separate various proteins from blood plasma. The process is based on the differential solubility of albumin and other plasma proteins that can be controlled by adjusting $\mathrm{pH}$, ethanol concentration, temperature, ionic strength, and protein concentration (Cohn et al., 1946; Matejtschuk et al., 2000). Valuable coagulation factors located in cryoprecipitate, such as factor VIII and von Willebrand factor, are removed by continuous flow centrifugation before the Cohn process. Subsequently, fibrinogen, immunoglobulins, and albumin are sequentially precipitated (Cohn et al., 1946; Kistler and Nitschmann, 1962; Matejtschuk et al., 2000).

We previously successfully purified PC from CFIV (Wang et al., 2010). During the purification of PC from CFIV, we found that the anticoagulant activity of PC was not correlated with its antigen and amidolytic activity. We hypothesized that the Cohn process influences the functional activity of PC. In this study, we investigated whether PC is affected during the Cohn process and evaluated the correlation between anticoagulant activity, amidolytic activity, and antigen of PC during the Cohn process.

\section{MATERIAL AND METHODS}

\section{Pretreatment of samples}

Six random batches of samples were provided by Guizhou Taibang Biological Products Co., Ltd. (Guiyang, China) for this study. For each batch, approximately $2500 \mathrm{~L}$ fresh frozen plasma was thawed at $1-6^{\circ} \mathrm{C}$ and the cryoprecipitate was removed by centrifugation. The cryosupernatant (CSP) was used to prepare various therapeutic proteins using the Cohn process. CSP, supernatant I (SI), supernatant II+III (SII+III), and CFIV, numbered from 1-4, respectively (Figure 1), were selected for the experiments. CFIV was re-dissolved in citratebuffered saline in a ratio of $1: 10(\mathrm{w} / \mathrm{v})$ for $5 \mathrm{~h}$ at $4^{\circ} \mathrm{C}$, and then centrifuged at $3500 \mathrm{~g}$ for $40 \mathrm{~min}$ at $4^{\circ} \mathrm{C}$. The supernatant was used in subsequent experiments.

\section{Anticoagulant activity assay}

The anticoagulant activity of PC was determined in a one-stage coagulation method based on activated partial thromboplastin time (aPTT). First, $70 \mu \mathrm{L}$ diluted sample and $70 \mu \mathrm{L}$ PC deficient plasma (American Diagnostica Inc., Stamford, CT, USA) were mixed and incubated at $37^{\circ} \mathrm{C}$ for $2 \mathrm{~min}$. Next, equal amounts aPTT regents (Chengdu Union Biotechnology Co., Ltd., Chengdu, China) and PC activator, Protac ${ }^{\circledR}$ (Hyphen Biomed, Neuville-sur-Oise, France) were added. After another incubation for $5 \mathrm{~min}$, calcium chloride was added and clotting was initiated. A direct relationship was observed between clotting time and PC anticoagu- 
lant activity. The anticoagulant activity of $\mathrm{PC}$ was converted using a calibration curve derived from a plasma calibrator (Hyphen Biomed) and the corresponding clotting time.
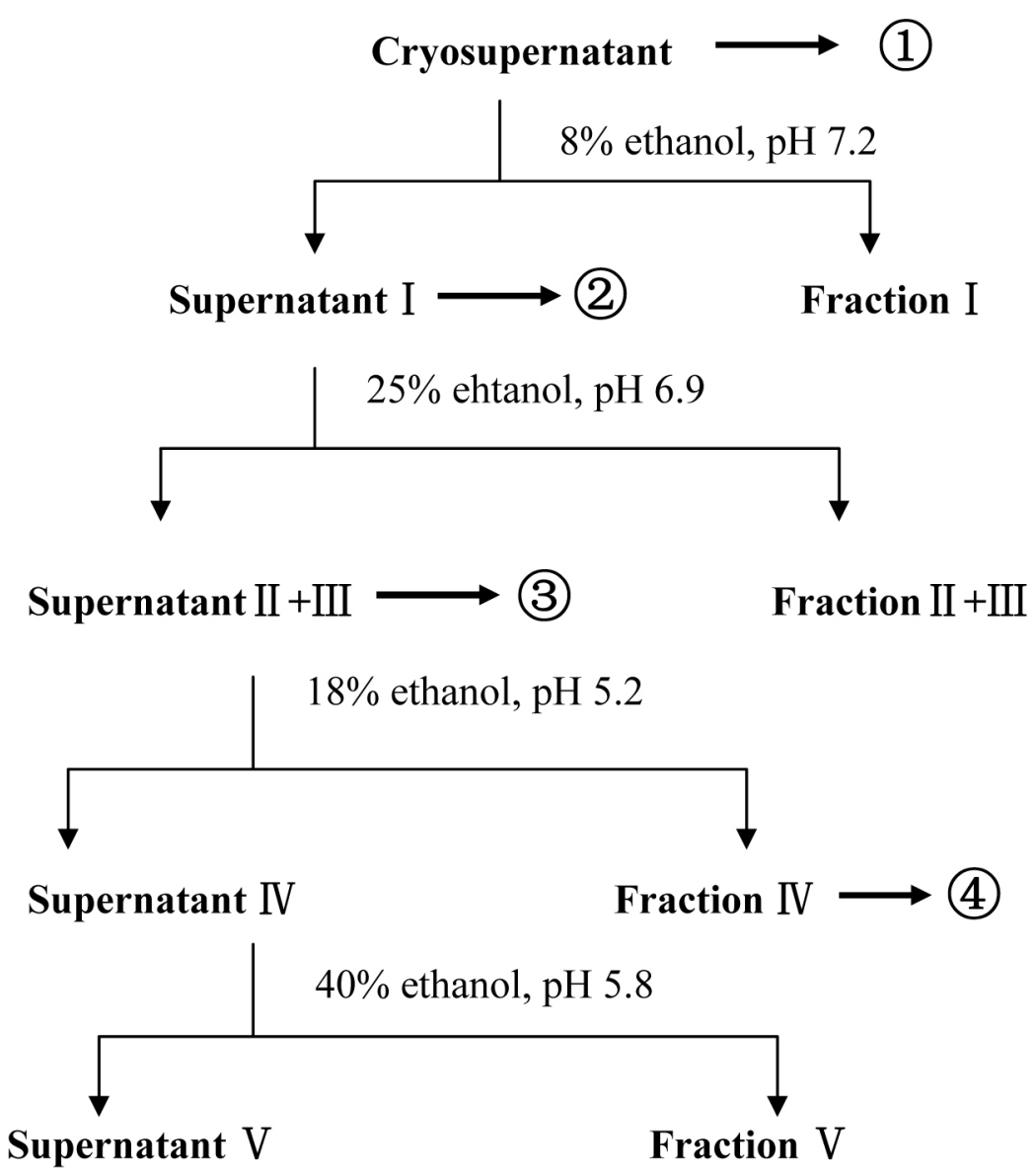

Figure 1. Flow diagram of the Cohn process. The samples numbered from 1 to 4 were used for the experiment. The 6 batches of cryosupernatant were 2470, 2480, 2460,2460, 2470, and $2470 \mathrm{~L}$, respectively. The data were 2700 , 2710, 2690, 2690, 2700, and $2700 \mathrm{~L}$ for supernatant I, 4020, 4040, 4010, 4030, 4020, and $4030 \mathrm{~L}$ for supernatant II+III, and 182, 194, 186, 196, 184, and $188 \mathrm{~kg}$ for Cohn fraction IV. The supernatant of redissolved Cohn fraction IV was $1820,1940,1860,1960,1840$, and $1880 \mathrm{~L}$, respectively.

\section{Amidolytic activity assay}

The amidolytic activity of PC was measured using a chromogenic substrate assay. To 96-well flat-bottom microtiter plates, we added $25 \mu \mathrm{L}$ plasma calibrator (Hyphen Biomed) in different dilution ratios and $75 \mu \mathrm{L}$ Protac ${ }^{\circledR}$ (Hyphen Biomed) and incubated the plate at $37^{\circ} \mathrm{C}$ for 8 min to rapidly catalyze the conversion of $\mathrm{PC}$ into the active form, activated protein $\mathrm{C}$. Subsequently, $75 \mu \mathrm{L}$ CS-21(66) (Hyphen Biomed), the specific chromogenic substrate, was added and the mixture was incubated at $37^{\circ} \mathrm{C}$ for $10 \mathrm{~min}$. Hydrolysis was terminated by adding $75 \mu \mathrm{L} 50 \%$ glacial acetic acid. Activated protein C specifically cleaves the substrate and re- 
leases para-nitroaniline. The color was measured at $405 \mathrm{~nm}$ using SpectraMax M2 ${ }^{\mathrm{e}}$ (Molecular Devices, Sunnyvale, CA, USA). For the endpoint method, the calibration curve was obtained by plotting on the abscissae the amidolytic activity of PC in the plasma calibrator with different dilutions and on the ordinate, the corresponding absorbance. PC amidolytic activities in the tested samples were directly calculated according to the calibration curve.

\section{Antigen content assay}

The antigen content of $\mathrm{PC}$ was quantified using an enzyme-linked immunosorbent assay (ELISA). A kit for this test was purchased from Hyphen Biomed. Diluted test samples were introduced into microwells pre-coated with a rabbit polyclonal antibody specific for human protein $\mathrm{C}$. After incubation for $1 \mathrm{~h}$ at room temperature, the wells were washed 5 times. Next, horseradish peroxidase-conjugated anti-(H)-PC immunoconjugate (a rabbit polyclonal antibody specific to human protein $\mathrm{C}$ ) was added to the microwells. After washing, the peroxidase substrate, tetramethylbenzidine in the presence of hydrogen peroxide, was introduced. After incubation for $5 \mathrm{~min}$ at room temperature, the reaction was stopped with $0.45 \mathrm{M}$ sulfuric acid. The absorbance was measured at $450 \mathrm{~nm}$ (reference absorbance: $620 \mathrm{~nm}$ ) using Spectra$\mathrm{Max} \mathrm{M2}$. The absorption value was directly proportional to the antigen content of PC in the tested samples.

\section{Statistical analysis}

All experiments were carried out in triplicate. Data was analyzed to determine the group mean, with error bars reported as the standard deviation (SD). The Shapiro-Wilk test was to determine the normality of the distribution. Multi-group comparisons (anticoagulant activity, amidolytic activity, and antigen of PC in each step of the Cohn process) were performed using one-way analysis of variance followed by the Tukey multiple means comparison test. Comparisons of the same PC parameter in the different steps were accomplished using two-tailed, paired Student $t$-tests. Correlations among anticoagulant activity, amidolytic activity, and antigen in the 4 steps were computed using Spearman's rank correlation analysis. A P value $<0.05$ was considered to be statistically significant. In addition, statistical analyses were conducted using the SPSS statistics software, version 17.0 (SPSS Inc., Chicago, IL, USA).

\section{RESULTS}

To simplify the measurement data, the antigen content of PC was converted to functional activity based on the theoretical value of $1 \mathrm{IU}$ functional activity in $1 \mathrm{~mL}$ normal pooled plasma, which is equivalent to $4 \mu \mathrm{g}$ antigen of PC.

Mean levels and range of PC in samples from different steps during the Cohn process are shown in Table 1 . There were no significant changes $(<10 \% ; \mathrm{P} \geq 0.064)$ from CSP to SI. However, there was an acute decrease of approximately $34 \%$ from SI to SII+III $(\mathrm{P}<0.001)$. Anticoagulant activity, amidolytic activity, and antigen content were decreased by 88.4 ( $\mathrm{P}$ $<0.001)$, $48.2(\mathrm{P}<0.001)$, and 48.0\% $(\mathrm{P}<0.001)$, respectively, during CFIV compared to SII+III. PC levels continuously decreased from CSP to CFIV $(\mathrm{P}<0.001)$, with a total decline of $93.1,66.7$, and $67.8 \%$ for anticoagulant activity, amidolytic activity, and antigen content, respectively. 
Table 1. Anticoagulant activity, amidolytic activity, and antigen content of PC in CSP, SI, SII+III, and CFIV.

\begin{tabular}{|c|c|c|c|c|c|c|c|c|c|c|c|}
\hline Analyte & CSP & SI & $\begin{array}{c}\text { Changes } \\
(\%)\end{array}$ & $\mathrm{P}^{*}$ & SII+III & $\begin{array}{c}\text { Changes } \\
(\%)\end{array}$ & $\mathrm{P}^{*}$ & CFIV & $\begin{array}{c}\text { Changes } \\
(\%)\end{array}$ & $\begin{array}{c}\text { Total } \\
\text { changes } \\
(\%) \S\end{array}$ & $\mathrm{P}^{*}$ \\
\hline $\begin{array}{l}\text { Anticoagulant } \\
\text { activity }\left(10^{6} \mathrm{IU}\right)\end{array}$ & $\begin{array}{l}2.17 \pm 0.10 \\
(2.04-2.27)\end{array}$ & $\begin{array}{l}1.96 \pm 0.27 \\
(1.52-2.22)\end{array}$ & 9.7 & 0.064 & $\begin{array}{l}1.29 \pm 0.15 \\
(1.13-1.45)\end{array}$ & 34.2 & $\begin{array}{c}<0.0001 \\
(0.12-0.20)\end{array}$ & $0.15 \pm 0.03$ & 88.4 & 93.1 & $<0.0001$ \\
\hline $\begin{array}{l}\text { Amidolytic } \\
\text { activity }\left(10^{6} \mathrm{IU}\right)\end{array}$ & $\begin{array}{l}2.16 \pm 0.10 \\
(2.03-2.28)\end{array}$ & $\begin{array}{l}2.10 \pm 0.26 \\
(1.83-2.46)\end{array}$ & 2.8 & 0.483 & $\begin{array}{l}1.39 \pm 0.18 \\
(1.23-1.65)\end{array}$ & 33.8 & $\begin{array}{c}<0.0001 \\
(0.66-0.80)\end{array}$ & $0.72 \pm 0.05$ & 48.2 & 66.7 & $<0.0001$ \\
\hline $\begin{array}{l}\text { Antigen } \\
\text { content }\left(10^{6} \mathrm{IU}\right)\end{array}$ & $\begin{array}{l}2.42 \pm 0.10 \\
(2.26-2.54)\end{array}$ & $\begin{array}{l}2.29 \pm 0.32 \\
(1.84-2.63)\end{array}$ & 5.4 & 0.269 & $\begin{array}{l}1.50 \pm 0.15 \\
(1.34-1.69)\end{array}$ & 34.5 & $\begin{array}{c}<0.0001 \\
(0.75-0.87)\end{array}$ & $0.78 \pm 0.07$ & 48.0 & 67.7 & $<0.0001$ \\
\hline
\end{tabular}

$\mathrm{N}=6$ samples. Data are reported as means $\pm \mathrm{SD}$, followed by the range of the results in parentheses. Mean change in PC levels in that step vs the step of the previous measurement. Total change in PC levels from CSP to CFIV. *PC levels in that step are compared with that in CSP, using two-tailed, paired Student $t$-tests. Antigen content was converted to functional activity based on the theoretical value that there is $1 \mathrm{IU}$ functional activity in $1 \mathrm{~mL}$ normal pooled plasma, equivalent to $4 \mu \mathrm{g}$ antigen of $\mathrm{PC}$.

Figure 2 shows the total functional activity and antigen content of PC in the 4 steps of the Cohn process. In CSP, the anticoagulant activity, amidolytic activity, and antigen content of PC were similar, and the ratio of the 3 parameters was 1.0:1.0:1.1. Similarly, no significant difference was observed in SI (1.0:1.1:1.2) and SII+III (1.0:1.1:1.2). However, we observed significantly lower anticoagulant activity, approximately $90 \%$ less than amidolytic activity and antigen content in CFIV, with the ratio of 1.0:5.1:5.5 (Figure 2; $\mathrm{P}<0.001$ ). There were no significant differences in amidolytic activity and antigen in CFIV.

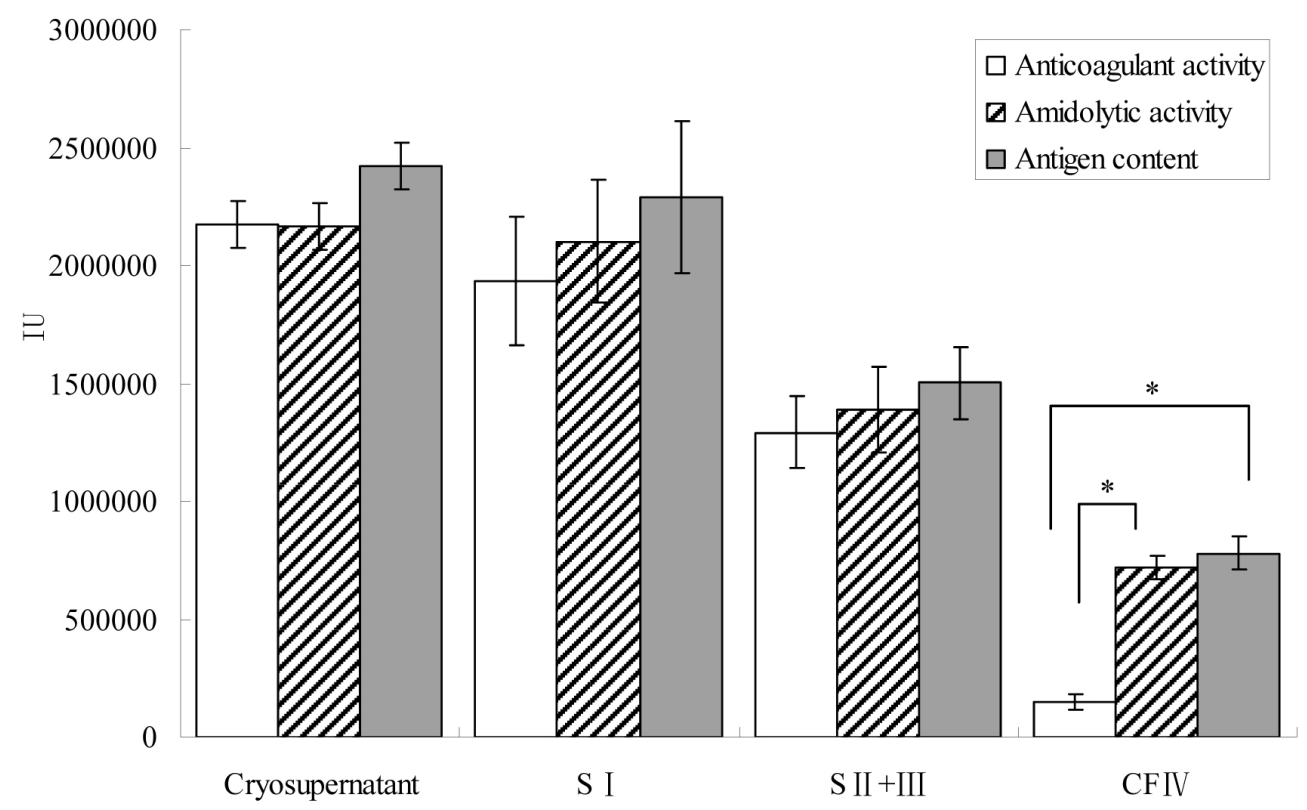

Figure 2. Anticoagulant activity, amidolytic activity and antigen of PC in CSP, SI, SII+III, and CFIV. Antigen content was converted to functional activity based on the theoretical value in $1 \mathrm{~mL}$ normal pooled plasma containing $1 \mathrm{IU}$ functional activity and $4 \mu \mathrm{g}$ antigen of PC. The statistical significances of anticoagulation activity, amidolytic activity, and antigen content of PC in the different steps of the Cohn process were evaluated, by one-way analysis of variance followed by the Tukey multiple comparison test. ${ }^{*} \mathrm{P}<0.001$. 
Spearman's rank correlations among anticoagulant activity, amidolytic activity, and antigen in the 4 steps are summarized in Table 2. Before the Cohn process, in CSP, Spearman's rank correlation coefficients of the $3 \mathrm{PC}$ parameters were high, with $\mathrm{r}_{\mathrm{s}}=0.921$ for anticoagulant $v s$ amidolytic activities, 0.896 for anticoagulant activity $v s$ antigen, and 0.832 for amidolytic activity $v s$ antigen $(\mathrm{P}<0.05$ for all comparisons). During the Cohn process, good correlations were observed for the 3 levels in SI and SII+III (the lowest $r_{s}=0.858 ; \mathrm{P}<0.05$ ). After the Cohn process, CFIV showed good correlation between amidolytic activity and antigen $\left(\mathrm{r}_{\mathrm{s}}=0.782 ; \mathrm{P}\right.$ $=0.039)$. However, no obvious correlation was found for anticoagulant activity $v s$ antigen $\left(\mathrm{r}_{\mathrm{s}}=\right.$ $0.223 ; \mathrm{P}=0.653)$ or anticoagulant $v s$ amidolytic activity $\left(\mathrm{r}_{\mathrm{s}}=0.236 ; \mathrm{P}=0.675\right)$.

Table 2. Rank correlations among anticoagulant activity, amidolytic activity, and antigen of PC in the 4 steps.

\begin{tabular}{|c|c|c|c|c|c|c|c|c|}
\hline \multirow[t]{2}{*}{ Analyte } & \multicolumn{2}{|c|}{ CSP } & \multicolumn{2}{|c|}{ SI } & \multicolumn{2}{|c|}{$\mathrm{SII}+\mathrm{III}$} & \multicolumn{2}{|c|}{ CFIV } \\
\hline & $\mathrm{r}_{\mathrm{s}}$ & P value* & $\mathrm{r}_{\mathrm{s}}$ & P value* & $r_{s}$ & P value* & $r_{\mathrm{s}}$ & P value* \\
\hline $\begin{array}{l}\text { Anticoagulant activity } \\
v s \text { amidolytic activity }\end{array}$ & 0.949 & 0.003 & 0.858 & 0.021 & 0.864 & 0.019 & 0.143 & 0.787 \\
\hline $\begin{array}{l}\text { Anticoagulant activity } \\
v s \text { antigen content }\end{array}$ & 0.845 & 0.034 & 0.906 & 0.013 & 0.943 & 0.004 & 0.2 & 0.704 \\
\hline $\begin{array}{l}\text { Amidolytic activity } \\
v s \text { antigen content }\end{array}$ & 0.886 & 0.019 & 0.867 & 0.015 & 0.881 & 0.02 & 0.782 & 0.038 \\
\hline
\end{tabular}

$\mathrm{r}_{\mathrm{s}}=$ Spearman's rank correlation coefficient. *Rank correlation coefficients were performed using the Spearman rank correlation test.

\section{DISCUSSION}

We attempted to purify PC from CFIV because it retains most of the PC in the plasma and therefore improves utilization of plasma. The byproduct CFIV is typically discarded by most plasma fractionators, but Bayer Corporation (Clayton, NC, USA) successfully purified $\alpha 1$-antitrypsin from Cohn fraction IV-1 and obtained large profits (Chen et al., 1998). Lee et al. $(2007,2008)$ and Rezania et al. (2007) demonstrated that it is feasible to purify PC from Cohn fraction IV-1. We previously successfully purified PC from CFIV (Wang et al., 2010). More importantly, the use of CFIV as the starting material does not interfere with the main fractionation of albumin. Although the PC concentrate may be contaminated with blood-borne viruses, only quarantined plasma has been used for this process in China. The plasma is stored frozen for at least 90 days until the donor returns and retests as negative for human immunodeficiency virus, heptatitis B virus, and hepatitis C virus. Virus removal (i.e., nanofiltration) and inactivation techniques (i.e., solvent/detergent treatment, pasteurization), robust methods widely used in the blood plasma industries, are also performed (Horowitz et al., 2004).

$\mathrm{PC}$ is a trace but extremely critical protein with anticoagulant, antiapoptic, and antiinflammatory properties in human blood plasma. There is little data regarding the PC levels retained in CFIV. Lee et al. $(2007,2008)$ reported that about $90 \%$ PC in plasma was retained in Cohn fraction IV-1. However, we observed that only approximately $32 \%$ PC in the initial material (CSP) was retained in CFIV. These discrepancies may have resulted from variations in the Cohn process.

The Cohn process is a milestone in the field of blood fractionation and it has been significantly modified over the past 60 years (Lane and Vallet, 1984; Matejtschuk et al., 2000). However, the Cohn process has not been thoroughly evaluated. Furthermore, the conventional process has not been modernized by manufacturing companies. Regardless, the process still 
serves as a cornerstone for plasma fractionation; its influence can be observed in the development of newer methods, such as ion exchange chromatography for intravenous immunoglobulin (Burnouf, 2007). Although there are some disadvantages to this method, such as high pollution and no modernization, the Cohn process is universal and practical for use by pharmacological and medical industries. There are more than 10 process variations but only 2 main processes, the original Cohn process and the Kistler and Nitschmann variation, are commonly used (Matejtschuk et al., 2000). In the original Cohn process, as displayed in Table 3, the conditions for fraction I were $8 \%$ ethanol, $\mathrm{pH} 7.2$, and $-3^{\circ} \mathrm{C}$, and those for fraction II + III were $25 \%$ ethanol, $\mathrm{pH} 6.9$, and $-5^{\circ} \mathrm{C}$. Fraction IV-1 was precipitated by decreasing the ethanol concentration from 25 to $18 \%$ and decreasing the $\mathrm{pH}$ from 6.9 to 5.2 . Fraction IV-4 was obtained by raising the ethanol concentration to $40 \%$ and the $\mathrm{pH}$ to 5.8 . For fraction $\mathrm{V}$, the $\mathrm{pH}$ was reduced to 4.8 while the ethanol concentration was maintained at $40 \%$ (Cohn et al., 1946). In the Kistler and Nitschmann variation, the precipitate A, which is equivalent to CFII+III, was precipitated at an ethanol concentration of $19 \%, \mathrm{pH} 5.85$, and $-3^{\circ} \mathrm{C}$. The precipitate $\mathrm{B}$, also known as fraction IV, was precipitated in $40 \%$ ethanol, $\mathrm{pH} 5.85$, and $-8^{\circ} \mathrm{C}$. Similarly to the original Cohn process, fraction V (precipitate $\mathrm{C}$ ) was obtained at $40 \%$ ethanol and $\mathrm{pH} 4.8$ (Table 3) (Kistler and Nitschmann, 1962). In general, 2 steps of the original Cohn process (Cohn fractions IV-1 and IV-4) were combined into 1 step (CFIV) in the Kistler and Nitschmann method. Currently, the original Cohn process is used by most American manufacturers, whereas the cost-effective and independent Kistler and Nitschmann variation has been widely accepted by many European and Asian fractionators (Matejtschuk et al., 2000). Therefore, Cohn fractions IV-1 and IV-4 are obtained in the United States, while CFIV is obtained in Asia and Europe using the different Cohn process variations. This may explain why PC levels in CFIV in the current study differed from those generated by the Cohn fraction IV-1 by Lee et al. (2008).

Table 3. Differences between the original Cohn process and Kistler and Nitschmann variation.

\begin{tabular}{|c|c|c|c|c|c|c|c|c|}
\hline & \multicolumn{5}{|c|}{ Original Cohn process } & \multicolumn{3}{|c|}{ Kistler and Nitschmann variation } \\
\hline & Fraction I & $\begin{array}{c}\text { Fraction } \\
\text { I+III }\end{array}$ & $\begin{array}{c}\text { Fraction } \\
\text { IV-1 }\end{array}$ & $\begin{array}{c}\text { Fraction } \\
\text { IV-4 }\end{array}$ & Fraction V & $\begin{array}{c}\text { Precipitate A } \\
(\text { Fraction II+III) }\end{array}$ & $\begin{array}{l}\text { Precipitate B } \\
(\text { Fraction IV) }\end{array}$ & $\begin{array}{l}\text { Precipitate C } \\
(\text { Fraction } \mathrm{V})^{\#}\end{array}$ \\
\hline Ethanol (\%) & 8 & 25 & 18 & 40 & 40 & 19 & 40 & 40 \\
\hline $\mathrm{pH}$ & 7.2 & 6.9 & 5.2 & 5.8 & 4.8 & 5.85 & 5.85 & 4.8 \\
\hline Temperature $\left({ }^{\circ} \mathrm{C}\right)$ & -3 & -5 & -5 & -5 & -5 & -3 & -8 & -8 \\
\hline
\end{tabular}

Data are from Cohn et al. (1946) and from Kistler and Nitschmann (1962). ${ }^{*}$ Corresponding denomination of the original Cohn process.

This study was carried out to assess the influence of the Cohn process on PC activity. The theoretical ratio of anticoagulant activity, amidolytic activity, and antigen content of PC in plasma is $1: 1: 1$. We found that the ratio was $1: 1: 1$ in CSP, which was identical in SI (1:1:1) and SII+III (1:1:1) during the Cohn process. Our results for CSP, SI, and SII+III agreed with the theoretical values. Interestingly, the anticoagulant activity of PC was significantly lower when compared to amidolytic activity and antigen content $(1: 5.1: 5.5 ; \mathrm{P}<0.001)$ in CFIV, while the ratio of amidolytic activity to antigen content of PC (1:1.1) was consistent with the theoretical value. Similarly, Spearman's rank correlation coefficients among anticoagulant activity, amidolytic activity, and antigen did not change significantly for CSP, SI, and SII+III, with the lowest $r_{s}=0.832(P<0.05)$. After the Cohn process, a significant correlation between 
amidolytic activity and antigen $\left(\mathrm{r}_{\mathrm{s}}=0.782, \mathrm{P}=0.039\right)$ was observed in CFIV. However, correlations for anticoagulant activity $v s$ antigen $\left(\mathrm{r}_{\mathrm{s}}=0.223, \mathrm{P}=0.653\right)$ and for anticoagulant $v s$ amidolytic activity $\left(\mathrm{r}_{\mathrm{s}}=0.236, \mathrm{P}=0.675\right)$ were significantly decreased. This indicates that in CFIV, anticoagulant activity significantly differed from amidolytic activity and antigen content. Thus, PC lost most of its anticoagulant activity but retained its amidolytic activity during the Cohn process.

Aggregate analysis of the anticoagulant and amidolytic properties of PC, as demonstrated through mutagenesis studies by several research groups (Sun et al., 2003; Kerschen et al., 2007; Mosnier et al., 2009; Nicolaes et al., 2010), revealed the different structure-function facets of PC. Numerous PC variants have been designed and assayed for their functional properties, and it appears that special surface areas denote different functional properties. To better understand the relationship between the structure and function of PC, Wildhagen et al. (2011) collected the available structure-function data of PC and created a perspective of the 3-D structure of PC. Mutagenesis studies have demonstrated the importance of a number of amino acid residues located in the Gla-domain of PC, such as residues Phe4, Leu5 and 8, Arg9 and 15, Glu6, 7, 16, 20, and 26, and His10, for PC anticoagulant activity (Wildhagen et al., 2011). Suitable $\mathrm{Ca}^{2+}$-dependent formation is important for maintaining the overall structure of the Gla-domain, which is essential for PC anticoagulant activity. Similarly, residues in the 37loop (Lys191-193), $\mathrm{Ca}^{2+}$-binding loop (Arg229-230), and autolysis loop (Glu309) of the serine protease domain are important for anticoagulant function by means of cleavage of activated factors V and VIII (Wildhagen et al., 2011). Furthermore, Asp71 in the epidermal growth factor domain plays a pivotal role in the interaction of $\mathrm{PC}$ with protein $\mathrm{S}$ and $\mathrm{Ca}^{2+}$. Site-direct mutagenesis studies indicate that PC will lose its anticoagulant function completely or partially, whereas its amidolytic activity is unaffected if one or more of the described residues are mutated. Anticoagulant and amidolytic activities simultaneously decrease when residue Ser336 in the 214-loop of the serine protease domain or Ser360 in the active site is mutated (Wildhagen et al., 2011). Collectively, the anticoagulant activity of PC may be affected by more critical residues (more than 30 variants) than the amidolytic activity (only several mutants). During the Cohn process, residues in the Gla-domain, 37-loop, $\mathrm{Ca}^{2+}$-binding loop, or autolysis loop may be damaged. These residues are critical for maintaining the $\mathrm{Ca}^{2+}$-dependent conformation of the Gla-domain, binding proteins to phospholipid, and inactivating activated factors $\mathrm{V}$ and VIII, which are essential elements for PC anticoagulant activity. Additionally, residues in the 214-loop and active site, which are essential for both anticoagulant and amidolytic activities, may not be affected. These results suggest that PC significantly loses its anticoagulant activity but retains its amidolytic activity during the Cohn process.

In summary, we found that compared with the PC antigen, anticoagulant activity was significantly affected with a more than $80 \%$ loss, while the amidolytic activity was relatively unaffected during the Cohn process. These results support the hypothesis that the Cohn process influences the anticoagulant activity of PC. Furthermore, in the Cohn process, only approximately $30 \%$ of $\mathrm{PC}$ in the plasma was retained in CFIV.

\section{ACKNOWLEDGMENTS}

Research supported by the Provincial Science and Technology Support Program of Sichuan (Grant \#2009SZ0217 and \#2014SZ0123) and a joint fund from the Institute of Blood Transfusion and Guizhou Taibang Biological Products Co., Ltd. 


\section{REFERENCES}

Athanasiadis G, Buil A, Souto JC, Borrell M, et al. (2011). A genome-wide association study of the protein C anticoagulant pathway. PLoS One 6: e29168.

Brummel-Ziedins KE, Orfeo T, Callas PW, Gissel M, et al. (2012). The prothrombotic phenotypes in familial protein C deficiency are differentiated by computational modeling of thrombin generation. PLoS One 7: e44378.

Burnouf T (2007). Modern plasma fractionation. Transfus. Med. Rev. 21: 101-117.

Chen SX, Hammond DJ, Lang JM and Lebing WR (1998). Purification of alpha 1 proteinase inhibitor from human plasma fraction IV-1 by ion exchange chromatography. Vox Sang. 74: 232-241.

Cohn EJ, Strong LE, Hughes WL, Mulford DJ, et al. (1946). Preparation and properties of serum and plasma proteins; a system for the separation into fractions of the protein and lipoprotein components of biological tissues and fluids. $J$. Am. Chem. Soc. 68: 459-475.

Dahlbäck B and Villoutreix BO (2003). Molecular recognition in the protein C anticoagulant pathway. J. Thromb. Haemost. 1: 1525-1534.

Dettenmeier P, Swindell B, Stroud M, Arkins N, et al. (2003). Role of activated protein C in the pathophysiology of severe sepsis. Am. J. Resp. Crit. Care 12: 518-524.

Dreyfus M, Ladouzi A, Chambost H, Gruel Y, et al. (2007). Treatment of inherited protein C deficiency by replacement therapy with the French purified plasma-derived protein C concentrate (PROTEXEL). Vox Sang. 93: 233-240.

Esmon CT (1989). The roles of protein C and thrombomodulin in the regulation of blood coagulation. J. Biol. Chem. 264: $4743-4746$.

Esmon CT (2012). Protein C anticoagulant system - anti-inflammatory effects. Semin. Immunopathol. 34: 127-132.

Griffin JH, Mosher DF, Zimmerman TS and Kleiss AJ (1982). Protein C, an antithrombotic protein, is reduced in hospitalized patients with intravascular coagulation. Blood 60: 261-264.

Hasstedt SJ, Bovill EG, Callas PW and Long GL (1998). An unknown genetic defect increases venous thrombosis risk, through interaction with protein C deficiency. Am. J. Hum. Genet. 63: 569-576.

Heleen van Ommen C and Middeldorp S (2011). Thrombophilia in childhood: to test or not to test. Semin. Thromb. Hemost. 37: 794-801.

Horowitz B, Minor P, Morgenthaler JJ, Burnouf T, et al. (2004). WHO Expert Committee on Biological Standardization. World Health Organ. Tech. Rep. Ser. 924: 1-232, (backcover).

Hoshi S, Hijikata M, Togashi Y, Aoyagi T, et al. (2007). Protein C deficiency in a family with thromboembolism and identified gene mutations. Internal. Med. 46: 997-1003.

International Warfarin Pharmacogenetics Consortium and Klein TE, Altman RB, Eriksson N, Gage BF, et al. (2009). Estimation of the warfarin dose with clinical and pharmacogenetic data. N. Engl. J. Med. 360: 753-764.

Kerschen EJ, Fernandez JA, Cooley BC, Yang XV, et al. (2007). Endotoxemia and sepsis mortality reduction by nonanticoagulant activated protein C. J. Exp. Med. 204: 2439-2448.

Kisiel W (1979). Human plasma protein C isolation, characterization, and mechanism of activation by alpha-thrombin. $J$. Clin. Invest. 64: 761-769.

Kisiel W, Canfield WM, Ericsson LH and Davie EW (1977). Anticoagulant properties of bovine plasma protein C following activation by thrombin. Biochemistry 16: 5824-5831.

Kistler P and Nitschmann H (1962). Large scale production of human plasma fractions. Vox Sang. 7: 414-424.

Kroiss S and Albisetti M (2010). Use of human protein C concentrates in the treatment of patients with severe congenital protein C deficiency. Biologics 4: 51-60.

Lane RS and Vallet L (1984). Human albumin and plasma protein fraction. Lancet 323: 1245-1246.

Lee JJ, Bruley DF and Kang KA (2007). Effect of $\mathrm{pH}$ and imidazole on protein C purification from Cohn fraction IV-1 by IMAC. Adv. Exp. Med. Biol. 599: 61-66.

Lee JJ, Bruley DF and Kang KA (2008). Manipulation of the affinity between protein and metal ions by imidazole and $\mathrm{pH}$ for metal affinity purification of protein C from Cohn fraction IV-1. Adv. Exp. Med. Biol. 614: 93-100.

Marlar RA, Montgomery RR, Madden RM, Sills RH, et al. (1992). Protein C survival during replacement therapy in homozygous protein C deficiency. Am. J. Hematol. 41: 24-31.

Matejtschuk P, Dash CH and Gascoigne EW (2000). Production of human albumin solution: a continually developing colloid. Br. J. Anaesth. 85: 887-895.

Miletich J, Sherman L and Broze G Jr (1987). Absence of thrombosis in subjects with heterozygous protein C deficiency. N. Engl. J. Med. 317: 991-996.

Mosnier LO, Yang XV and Griffin JH (2007). Activated protein C mutant with minimal anticoagulant activity, normal cytoprotective activity, and preservation of thrombin activable fibrinolysis inhibitor-dependent cytoprotective

Genetics and Molecular Research 14 (1): 860-870 (2015)

CFUNPEC-RP www.funpecrp.com.br 
functions. J. Biol. Chem. 282: 33022-33033.

Mosnier LO, Zampolli A, Kerschen EJ, Schuepbach RA, et al. (2009). Hyperantithrombotic, noncytoprotective Glu149Alaactivated protein C mutant. Blood 113: 5970-5978.

Ní Ainle F, O’Donnell JS, Johnson JA, Brown L, et al. (2011). Activated protein C N-linked glycans modulate cytoprotective signaling function on endothelial cells. J. Biol. Chem. 286: 1323-1330.

Nicolaes GA, Bock PE, Segers K, Wildhagen KC, et al. (2010). Inhibition of thrombin formation by active site mutated (S360A) activated protein C. J. Biol. Chem. 285: 22890-22900.

Petraglia AL, Marky AH, Walker C, Thiyagarajan M, et al. (2010). Activated protein C is neuroprotective and mediates new blood vessel formation and neurogenesis after controlled cortical impact. Neurosurgery 66: 165-172.

Rezania S, Ahn DG and Kang KA (2007). Separation of protein C from Cohn Fraction IV-1 by mini-antibody. Adv. Exp. Med. Biol. 599: 125-131.

Schramm W (1993). Treatment of coumarin-induced skin necrosis with a monoclonal antibody purified protein C concentrate. Arch. Dermatol. 129: 753-756.

Sun YH, Shen L and Dahlbäck B (2003). Gla domain-mutated human protein C exhibiting enhanced anticoagulant activity and increased phospholipid binding. Blood 101: 2277-2284.

Tang L, Guo T, Yang R, Mei H, et al. (2012). Genetic background analysis of protein C deficiency demonstrates a recurrent mutation associated with venous thrombosis in Chinese population. PLoS One 7: e35773.

Toussaint S and Gerlach H (2009). Activated protein C for sepsis. N. Engl. J. Med. 361: 2646-2652.

Wang ZK, Li CQ, Lin FZ, Cao HJ, et al. (2010). Isolation and purification of human protein C from Cohn fraction IV. Vox Sang. 99: 234-234.

Wildhagen KC, Lutgens E, Loubele ST, ten Cate H, et al. (2011). The structure-function relationship of activated protein C. Lessons from natural and engineered mutations. Thromb. Haemost. 106: 1034-1045.

Wu HP and Bruley DF (2002). Chelator, metal ion and buffer studies for protein C separation. Comp. Biochem. Physiol. A Mol. Integr. Physiol. 132: 213-220. 